\title{
First record of anomalous otoliths of Menticirrhus americanus in the South Atlantic
}

\author{
Barbara Maichak de Carvalho' (D) | Alejandra Vanina Volpedo ${ }^{2}$ (D) | \\ Cristiano Queiroz Albuquerque ${ }^{3}$ (i) | Luís Fernando Fávaro ${ }^{4}$ (i)
}

\author{
${ }^{1}$ Programa de Pós-Graduação em Engenharia \\ Ambiental, Departamento de Engenharia - \\ UFPR, Centro Politécnico, Curitiba, Brazil \\ ${ }^{2}$ CONICET, Instituto de Investigaciones \\ en Producción Animal (INPA), Centro de \\ Estudios Transdisciplinarios del Agua \\ (CETA), Universidad de Buenos Aires, \\ Buenos Aires, Argentina \\ ${ }^{3}$ Departamento de Ciências \\ Animais, Universidade Federal Rural do \\ Semi-Árido, Mossoró, Brazil \\ ${ }^{4}$ Laboratório de Reprodução e Comunidade \\ de Peixes, Setor de Ciências Biológicas, \\ Centro Politécnico, Universidade Federal do \\ Paraná (UFPR), Curitiba, Brazil

\section{Correspondence} \\ Barbara Maichak de Carvalho, Programa de \\ Pós-Graduação em Engenharia Ambiental, \\ Departamento de Engenharia - UFPR, \\ Centro Politécnico, CEP 81531-970, Bairro \\ Jardim das Américas, Curitiba, Paraná, Brazil. \\ Email: bmaicarvalho@gmail.com

\section{Funding information} \\ Conselho Nacional de Desenvolvimento \\ Científico e Tecnológico, Grant/Award \\ Number: 141267/2015-1 ; Coordenação \\ de Aperfeiçoamento de Pessoal de Nível \\ Superior, Grant/Award Number: 043/13 \\ and code 001; Consejo Nacional de \\ Investigaciones Científicas y Técnicas
}

\begin{abstract}
Sagitta otoliths are usually formed of calcium carbonate polymorphs as aragonite. The objective of this study was to verify which carbonate polymorph is predominant in the sagitta otolith of Menticirrhus americanus and check whether this pattern remains in otoliths with morphological alterations. Otoliths of $M$. americanus were obtained from five sites on the southeast-south coast of Brazil (São Sebastião (SS) $23^{\circ} 45^{\prime} \mathrm{S}-45^{\circ} 24^{\prime} \mathrm{O}, n=29$; Cananéia-Iguape Estuarine Complex (CI) $25^{\circ} 02^{\prime} \mathrm{S}-47^{\circ} 54^{\prime} \mathrm{O}$, $n=30$; Paranaguá Estuarine Complex (PEC) $25^{\circ} 28^{\prime} \mathrm{S}-48^{\circ} 20^{\prime} \mathrm{O}, n=35$; Itapoá (IT) $26^{\circ} 07^{\prime} \mathrm{S}-48^{\circ} 36^{\prime} \mathrm{O}, n=31$; Laguna (LA) $28^{\circ} 28^{\prime} \mathrm{S}-48^{\circ} 46^{\prime} \mathrm{O}, n=13$ ). The characterization of carbonate polymorphs of otoliths was performed through Raman spectroscopy, a photonic and non-destructive technique that analyzes molecular vibrations induced by laser. We analyzed 138 pairs of M. americanus otoliths, of which eight otoliths from different pairs presented morphological alterations (SS $n=1$, CEP $n=5$, IT $n=1$, LA $n=1$ ). The Raman spectra show that normal otoliths, that is, without morphological alterations, presented only aragonite in their structure. Among the otoliths that presented morphological alterations, the Raman spectra allowed to identify in six otoliths the deposition of aragonite and in only two otoliths the deposition of vaterite (one specimen of the PEC and one of SS).
\end{abstract}

\section{1 | INTRODUCTION}

Otoliths are metabolically inert carbonate structures, that is, after their formation there are no chemical alterations or reabsorption. They are sensory organs immersed in the endolymph that help in the balance and hearing of the fish (Ladich \& Schulz-Mirbach, 2016). Chemically, they are mainly composed of calcium carbonate, precipitated as aragonite, under a high molecular weight protein matrix. This process is regulated by hormones and influenced by environmental factors (Popper \& Fay, 2011).

Precipitation of calcium carbonate may occur in the form of vaterite and calcite, this change in carbonate crystallization has been attributed to chemical changes in endolymph and/or environmental stress (David \& Grimes, 1994; Gauldie, 1993; Tomás, Geffen, Allen, \& Berges, 2004). Experimental studies have pointed out that changes in physicochemical parameters such as $\mathrm{pH}$ and temperature of the marine environment can cause alterations in the acidity of endolymph, a liquid in which otoliths are immersed (Martino, Doubleday, Woodcock, \& Gillanders, 2017;Munday, Hernaman, Dixson, \& Thorrold, 2011). Due to the alkaline property of endolymph, saturation and deposition of aragonite occurs in otoliths (Payan, Pontual, Boeuf, \& Mayer-Gostan, 2004). Alterations in the endolymph $\mathrm{pH}$ can favor the precipitation of vaterite and calcite, which are less dense than aragonite (Holmberg et al., 2019). 
Studies have shown that crystallographic anomalies may be due to a variety of factors, such as physical trauma in the macula (Strong, Neison, \& Hunt, 1986), deficient nutrition and high phosphate concentration in water (David \& Grimes, 1994), high population density in captivity (Sweeting, Beamish, \& Neville, 2004) and salinization of the environment (Avigliano, Tombari, \& Volpedo, 2012). For demersal species, it has been reported different frequencies of occurrence of anomalies: Pollachius virens 48\% of anomalous otoliths (Strong et al., 1986), Oncorhynchus kisutch 16,7\% (Sweeting et al., 2004), Platichthys flesus 43\% (Neves, Guedes, Valentim, Campos, \& Freitas, 2017); Pseudorhombus malayanus 50\% (Manizadeh, Teimori, Askari Hesni, \& Motamedi, 2018). Species of the family Sciaenidae presented lower frequency of anomalies in relation to the species mentioned above (David \& Grimes, 1994; Béarez, Carlier, Lorand, \& Parodi, 2005).

The demersal species, Menticirrhus americanus (Linnaeus, 1758), object of this study, belongs to the family Sciaenidae and is distributed between latitudes $41^{\circ} \mathrm{N}$ and $51^{\circ} \mathrm{S}$ (Chao et al., 2015). Menticirrhus americanus is an important resource in the trophic web of ichthyophagous in the southern Brazilian region (Bornatowski, Braga, Abilhôa, \& Corrêa, 2014). The species dwells estuarine areas, usually associated with unconsolidated substrate and makes use of the internal continental shelf (Passos et al., 2013). This study aimed to evaluate the occurrence of macroscopic and crystallographic morphological anomalies in M. americanus otoliths on the southeast-south coast of Brazil.

\section{2 | MATERIALS AND METHODS}

Specimens of M. americanus were caught and purchased from the fishing fleet between June 2015 and May 2016 in five sites along the southeast-south coast of Brazil (Figure 1).

Along the sampled region there are densely urbanized locations with the presence of ports and petroleum terminals (SS $-23^{\circ} \mathrm{S}, \mathrm{CEP}$ - $25^{\circ} \mathrm{S}$ and IT $-26^{\circ} \mathrm{S}$ ) and without terminals (LA - 28 $8^{\circ} \mathrm{S}$ ) (Table 1). Sampling was also performed in a region with less urbanization, without ports and petroleum complexes $\left(\mathrm{Cl}-25^{\circ} \mathrm{S}\right)$ (Table 1). The lowest water temperatures are recorded for Laguna and the highest for São Sebastião (Table 1).

Menticirrhus americanus specimens were measured for total length (TL) in cm, total weight (TW) in grams. The otoliths were removed, cleaned and stored dry and classified morphologically (Corrêa \& Viana, 1992). Areas with alterations were photographed in a scanning electron microscope. From the microphotographs, the crystals were morphologically classified: calcite crystals were classified as cuboidal with larges crystals, botryoidal and fusiforms vaterite and laths and blocks aragonite according to Béarez et al., (2005); Gauldie (1993); Tzeng et al., (2007) and Kern et al., (2017).

The crystallographic characterization of otoliths was performed using a Confocal Raman Witec alpha 300R spectrometer, the spectra were excited by the $532 \mathrm{~nm}$, using an 50x microscope objective, laser penetration was $200 \mu \mathrm{m}$ and the results were collected 10 times with an exposure time of $3 \mathrm{~s}$. According to Melancon, Fryer, Ludsin, Gagnon, and Yang (2005), aragonite and vaterite in otoliths are characterized by vibrations at different wavelengths, in which aragonite is characterized by a more intense vibration between 1,075 and $1,090 \mathrm{~cm}^{-1}$ and two small vibrations between 100 and $400 \mathrm{~cm}^{-1}$. Vaterite differs from aragonite because it presents two more intense vibrations between 1,075, 1,081 and $1,090 \mathrm{~cm}^{-1}$ and three small vibrations between 100 e $400 \mathrm{~cm}^{-1}$.

\section{3 | RESULTS}

For the morphological classification were observed 676 otoliths of M. americanus. Morphological alterations were found in 8 otoliths of 676 observed, representing $1.18 \%$ of all otoliths observed. The highest sampling occurred in the PEC with 538 specimens, followed by $\mathrm{Cl}, \mathrm{IT}$, SS and LA, with 45, 44, 32 and 17, respectively. The frequency of otolith anomalies differs between sites, in the PEC we observed five otoliths with alterations ( $1 \%$ frequency) and one otolith in SS (3\% frequency), IT ( $2 \%$ frequency) and LA ( $6 \%$ frequency). No otolith with morphological anomaly was observed in $\mathrm{Cl}$.

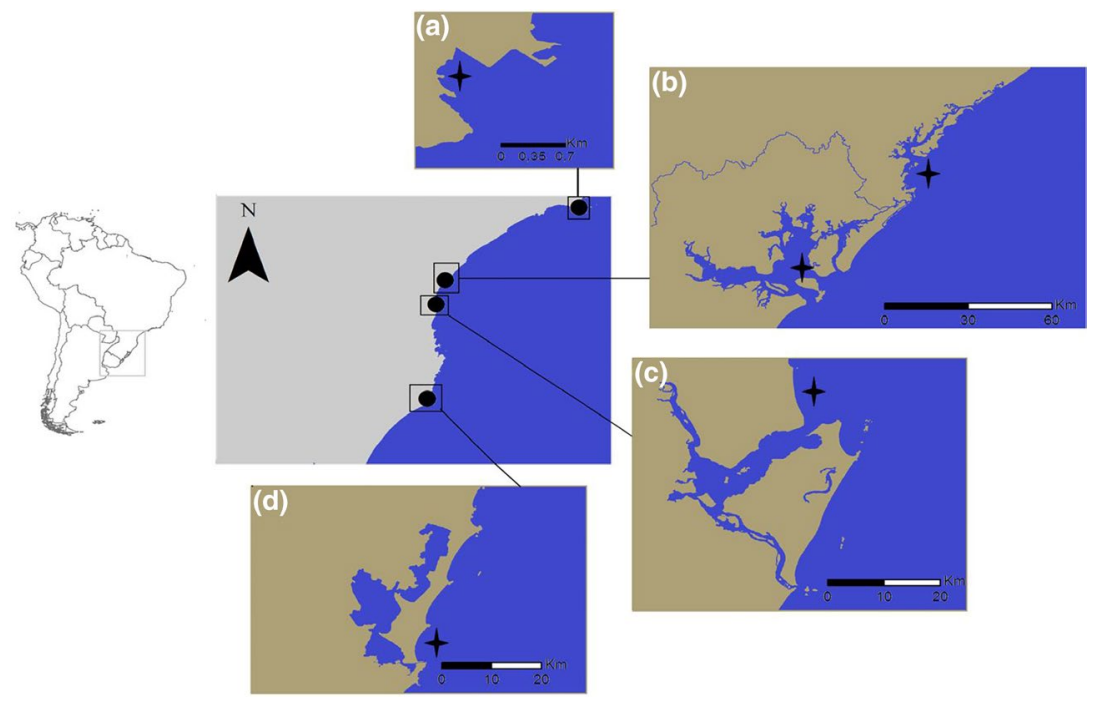

FIGURE 1 Sampling sites of Menticirrhus americanus specimens along the South Atlantic. (a) Location of the sampling sites at latitude $23^{\circ} \mathrm{S}$ - São Sebastião (SS), (b) at latitude $25^{\circ} \mathrm{S}$ Cananéia $(\mathrm{Cl})$ and Paranaguá Estuarine Complex (PEC), (c) at latitude $26^{\circ} \mathrm{S}$ - Itapoá (IT) and (d) at latitude $28^{\circ} \mathrm{S}$ - Laguna (LA). Stars indicate the sampling sites 
TABLE 1 Physical-chemical parameters and population of the environments in which sagittae otoliths were sampled M. americanus from the South Atlantic

\begin{tabular}{|c|c|c|c|c|}
\hline Site & Pop & $T^{\circ} \mathrm{C}$ & Sal & Author \\
\hline São Sebastião (SS) & $>85 \mathrm{mil}$ & $15-28$ & $32-35$ & Siegle et al. (2017) \\
\hline $\begin{array}{l}\text { Cananéia-Iguape Estuarine } \\
\text { Complex (Cl) }\end{array}$ & $<13 \mathrm{mil}$ & $20-26$ & $<35$ & Barcellos et al. (2005) \\
\hline $\begin{array}{l}\text { Paranaguá Estuarine } \\
\text { Complex (PEC) }\end{array}$ & $>140$ mil & $20-26$ & $<33.2$ & $\begin{array}{l}\text { Mizerkowski et al. } \\
\text { (2012) }\end{array}$ \\
\hline Itapoá (IT) & $>14 \mathrm{mil}$ & $17.3-26.8$ & $24.7-36$ & Carvalho et al. (1998) \\
\hline Laguna (LA) & $>51 \mathrm{mil}$ & $<18$ & $>35.5$ & Campos et al. (2013) \\
\hline
\end{tabular}

otoliths. The low frequency of morphologically anomalous otoliths observed for M. americanus in the analyzed region indicates that species of the family Sciaenidae present low frequency of alterations as also observed in other studies (David \& Grimes, 1994; Béarez, Carlier, Lorand \& Parodi, 2005). However, other demersal species presented frequency of anomalies higher than $30 \%$, which can be a consequence of high population density in captivity (Sweeting et al., 2004) and salinization (Neves et al., 2017).

According to the SEM images, crystals precipitated in altered areas of the M. americanus otoliths were morphologically classified as calcite, vaterite and aragonite. However, Raman microscopy indicates only the precipitation of vaterite and aragonite in the anomalous otoliths analyzed. The morphological alteration associated with vaterite and aragonite has already been reported for other species (Gauldie, 1993; David \& Grimes, 1994; Béarez et al., 2005; Neves et al., 2017). But the presence of vaterite in $M$. americanus otoliths is presented here for the first time. The precipitation of vaterite in the otoliths may be, among other factors, a consequence of the reduction in the endolymph $\mathrm{pH}$ (Holmberg et al., 2019). According to Feng (2011), vaterite is the most unstable calcium carbonate and has more frequent deposition under extreme conditions of $\mathrm{pH}$, temperature and pressure. As vaterite becomes more frequent under extreme conditions, its presence suggests that modifications occurred in the endolymph $\mathrm{pH}$ of two individuals of $\mathrm{M}$. americanus that presented anomalous otoliths with carbonate precipitated as vaterite. Due

This study showed the occurrence of morphological alterations associated with the deposition of vaterite and aragonite in M. americanus

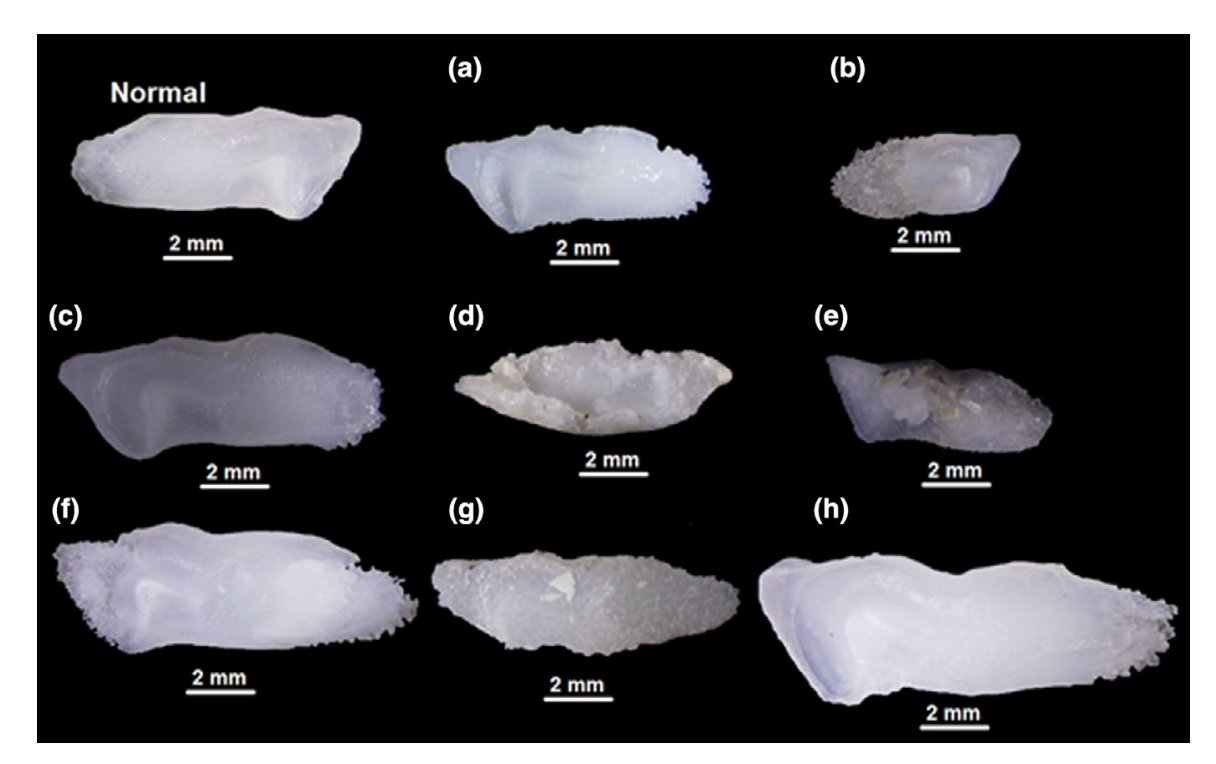

FIGURE 2 Anomalous sagitta otoliths of Menticirrhus americanus from the South Atlantic (a-h) and without alterations (normal) 

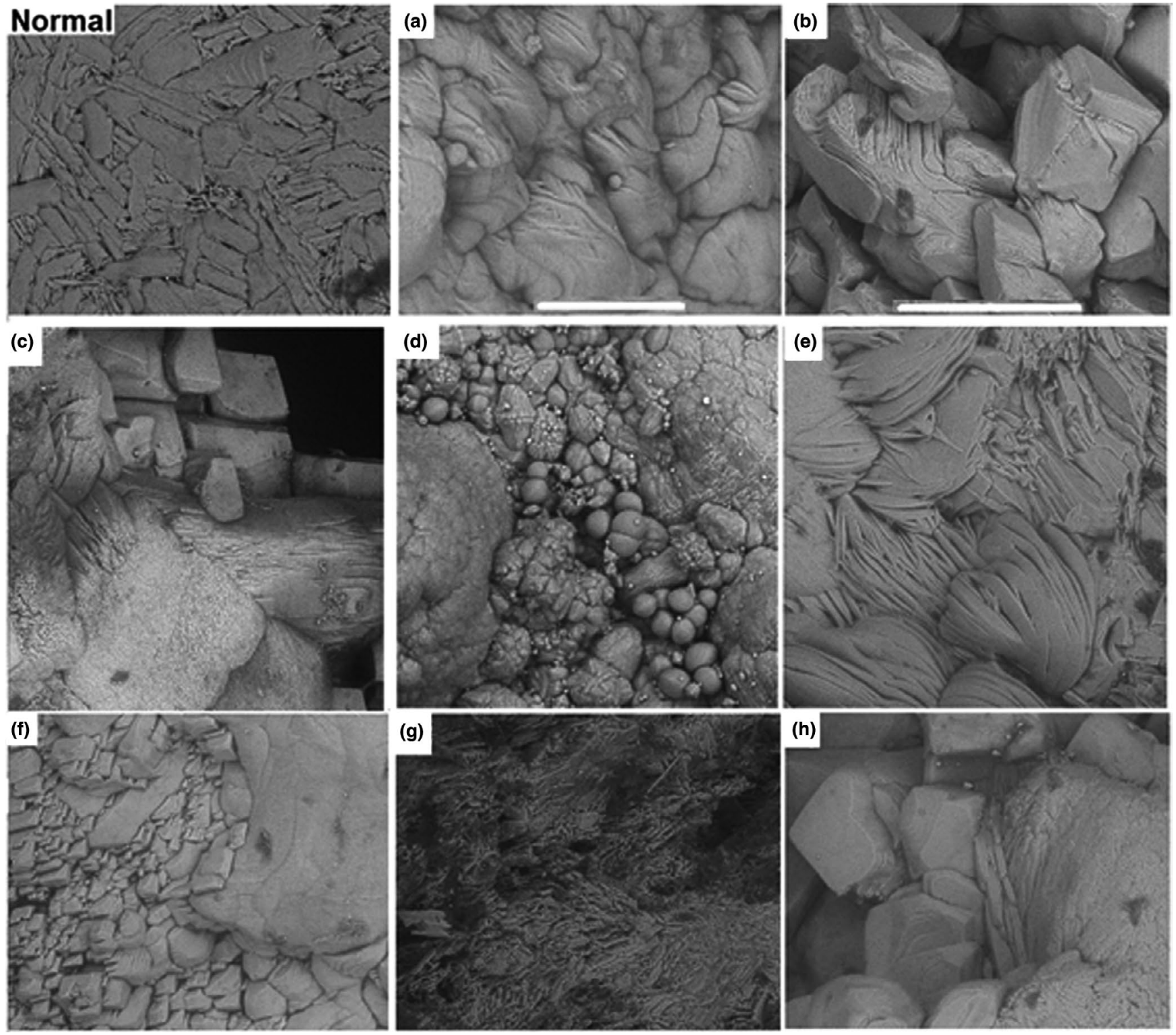

FIGURE 3 Scanning micrograph of the anomalous and normal sagitta otoliths of M. americanus from the South Atlantic shelf. Scale a, d, Normal $=20 \mu \mathrm{m}$ and $\mathrm{b}, \mathrm{c}, \mathrm{e}, \mathrm{f}, \mathrm{g}, \mathrm{h}=50 \mu \mathrm{m}$
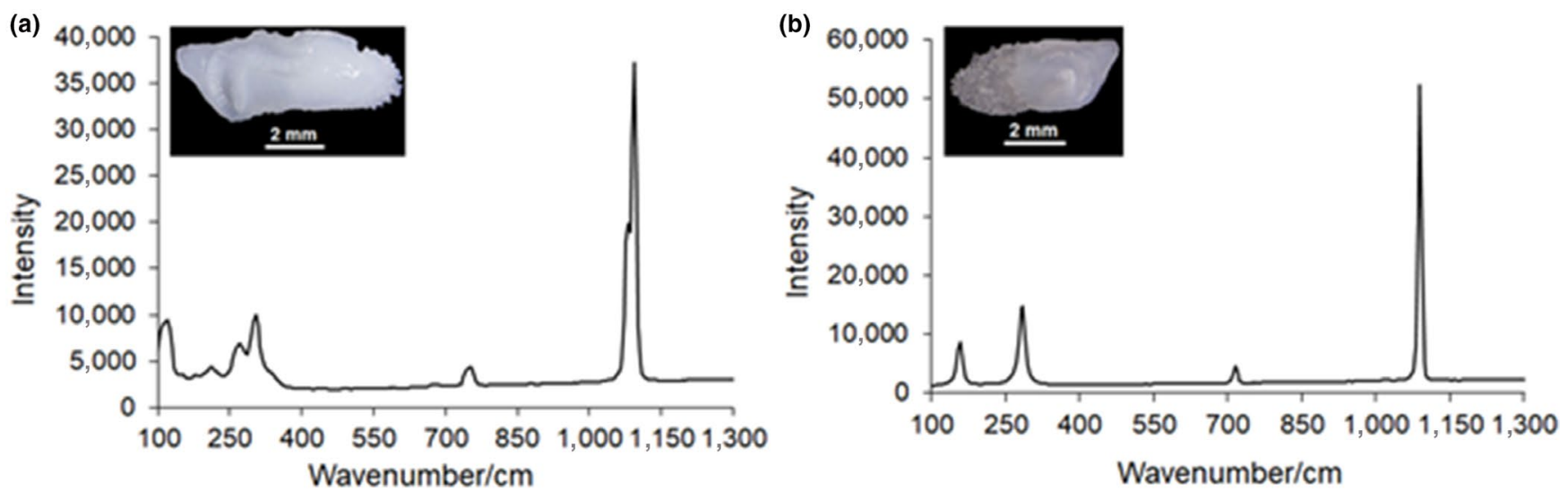

FIG URE 4 Raman spectra of sagitta otoliths with morphological alterations of Menticirrhus americanus sampled in five sites of the South Atlantic. (a) vaterite and (b) aragonite 
to the low density of vaterite, specimens with this crystallization in the otoliths may present hearing deficits becoming more susceptible to predation and/or capture by fishing (Oxman et al., 2007).

Anomalous otoliths were not observed in IC; this environment houses the smallest population and no port or petroleum terminals, differing from the other environments that presented alterations. According to David \& Grimes (1994), the high introduction of phosphate in the aquatic environment would affect the solubility of the endolymph, thus causing an interruption in the deposition of aragonite and resulting in morphological changes in the otoliths. PEC, SS, IT and LA are more populated habitat in comparison to $\mathrm{Cl}$ and with port and petroleum terminals. These differences could indicate anthropic influence on the presence of anomalous otoliths. However, in this study, data are biased due to differences in sampling effort, hindering to reach a final conclusion on human influence in the presence of anomalies in otoliths.

The morphological alterations observed in sagitta otoliths of M. americanus had low frequency, being considered rare events in the analyzed population. Vaterite was present in only two morphologically anomalous otoliths and it is not possible to correlate it with morphological alterations in M. americanus.

\section{ACKNOWLEDGEMENTS}

The authors are grateful for funding from the project CAFP-BA/ SPU and 292/14 UFPR/Fundação Araucária. They also thank CONICET and UBACYT, Scholarship to the first author (CNPQ 141267/2015-1 and PNPD - CAPES), LAFMA (CEM-UFPR) for the stereomicroscope and the Olympus DP71 camera and the Centro de Microscopia Eletrônica (CME-UFPR) for the micrographs and the Raman spectra.

\section{ORCID}

Barbara Maichak de Carvalho iD https://orcid.org/0000-0001-7958-427X Alejandra Vanina Volpedo (iD https://orcid.org/0000-0003-3321-311X Cristiano Queiroz Albuquerque iD https://orcid.org/0000-0001-8960-1694 Luís Fernando Fávaro iD https://orcid.org/0000-0001-7306-5858

\section{REFERENCES}

Avigliano, E., Tombari, A., \& Volpedo, A. V. (2012). ¿El otolito de pejerrey (Odontesthes bonariensis), refleja el estrés ambiental? Biología Acuática, 27, 9-15.

Barcellos, R. L., Berbel, G. B. B., Braga, E. S., \& Furtado, V. V. (2005). Distribuição e características do fósforo sedimentar no sistema estuarino lagunar de Cananéia-Iguape, estado de São Paulo, Brasil. Geochimica Brasiliensis, 19(1), 22-36.

Béarez, P., Carlier, G., Lorand, J. P., \& Parodi, G. C. (2005). Destructive and non-destructive microanalysis of biocarbonates applied to anomalous otoliths of archaeological and modern sciaenids (Teleostei) from Peru and Chile. Comptes Rendus Biologies, 328, 243-252. https://doi. org/10.1016/j.crvi.2005.01.003
Bornatowski, H., Braga, R. R., Abilhôa, V., \& Corrêa, M. F. M. (2014). Feeding ecology and trophic comparisons of six shark species in a coastal ecosystem off southern Brazil. Journal of Fish Biology, 85, 246-263. https://doi.org/10.1111/jfb.12417

Campos, P. C., Moller, O. O., Piola, A., \& Palma, E. D. (2013). Seasonal variability and coastal upwelling near Cape Santa Marta (Brazil). Journal Geophysicao Research: Oceans, 118, 1420-1433. https://doi. org/10.1002/jgrc.20131

Carvalho, J. L. B., Schettini, C. A. F., \& Ribas, T. M. (1998). Estrutura termohalina do litoral centro-norte catarinense. Notas Tecnicas Facimar, 2, 181-197.

Chao, N. L., Frédou, F. L., Haimovici, M., Peres, M. B., Polidoro, B., Raseira, M., ... Carpenter, K. (2015). A popular and potentially sustainable fishery resource under pressure-extinction risk and conservation of Brazilian Sciaenidae (Teleostei: Perciformes). Global Ecology and Conservation, 4, 117-126. https://doi.org/10.1016/j.gecco.2015.06.002

Corrêa, M. F. M., \& Viana, M. S. (1992). Catálogo dos otólitos sagitta de Sciaenidae (Ostheichthys - Perciformes) do litoral do estado do Paraná, Brasil. Nerítica, 7, 13-41.

David, A. D., \& Grimmes, B. C. (1994). Vaterite sagittal otolith hatchery reared juvenile red drums. The Progessive Fish-Culturist, 56, 301-303.

Feng, Q. (2011). Principles of Calcium-Based Biomineralization. In W. E. G. Muller (Ed.), Molecular Biomineralization, Progress in Molecular and Subcellular Biology (Vol. 52, pp. 141-197). https://doi. org/10.1007/978-3-642-21230-7_6

Gauldie, R. W. (1993). Polymorphic cristalline structure of fish otolith. Journal of Morphology, 218, 1-28. https://doi.org/10.1002/ jmor.1052180102

Holmberg, R. J., Wilcox-Freeburg, E., Rhyne, A. L., Tlusty, M. F., Stebbins, A., Nye, S. W. Jr, ... Hannigan, R. E. (2019). Ocean acidification alters morphology of all otolith types in Clark's anemonefish (Amphiprion clarkii). PeerJ, 7, 1-24. https://doi.org/10.7717/peerj.6152

Kern, Z., Kázmér, M., Müller, T., Specziár, A., Németh, A., \& Váczi, T. (2017). Fusiform vateritic inclusions observed in European eel (Anguilla anguilla L.) sagittae. Acta Biologica Hungarica, 68(3), 267278. https://doi.org/10.1556/018.68.2017.3.4

Ladich, F., \& Schulz-Mirbach, T. (2016). Diversity in fish auditory systems: One of the riddles of sensory biology. Frontiers in Ecology and Evolution, 4, 1-27. https://doi.org/10.3389/fevo.2016.00028

Manizadeh, N., Teimori, A., Askari Hesni, M., \& Motamedi, M. (2018). Abnormal otoliths in the marine fishes collected from the Persian Gulf and the Gulf of Oman. Acta Ichthyologica et Piscatoria, 48(2), 143-151. https://doi.org/10.3750/AIEP/2350

Martino, J., Doubleday, Z. A., Woodcock, S. H., \& Gillanders, B. M. (2017). Elevated carbon dioxide and temperature affects otolith development, but not chemistry, in a diadromous fish. Journal of Experimental Marine Biology and Ecology, 495, 57-64. https://doi.org/10.1016/j. jembe.2017.06.003

Melancon, S., Fryer, B. J., Ludsin, S. A., Gagnon, J. E., \& Yang, Z. (2005). Effects of crystal structure on the uptake of metals by lake trout (Salvelinus namaycush) otoliths. Canadian Journal of Fisheries Aquatic Science, 62, 2609-2619. https://doi.org/10.1139/F05-161

Mizerkowski, B. D., Hesse, K., Ladwig, N., Machado, E. C., Rosa, R., Araújo, T., \& Koch, D. (2012). Sources, loads and dispersion of dissolved inorganic nutrients in Paranaguá Bay. Ocean Dynamics, 62, 1409-1424. https://doi.org/10.1007/s10236-012-0569-x

Munday, P. L., Hernaman, V., Dixson, D. L., \& Thorrold, S. R. (2011). Effect of ocean acidification on otolith development in larvae of a tropical marine fish. Biogeosciences, 8, 1631-1641. https://doi.org/10.5194/ bg-8-1631-2011

Neves, V., Guedes, A., Valentim, B., Campos, J., \& Freitas, V. (2017). High incidence of otolith abnormality in juvenile European flounder Platichthys flesus from a tidal freshwater área. Marine Biology Research, 13, 933-941. https://doi.org/10.1080/17451 000.2017 .1331041 
Oxman, D. S., Barnett-Johnson, R., Smith, M. E., Coffin, A., Miller, D. L., Josephson, R., \& Popper, A. N. (2007). The effect of vaterite deposition on sound reception, otolith morphology, and inner ear sensory epithelia in hatchery-reared Chinook salmon (Oncorhynchus tshawytscha). Canadian Journal of Fisheries Aquatic Science, 64, 14691478. https://doi.org/10.1139/F07-106

Passos, A. C., Contente, R. F., Abbatepaulo, F. V., Spach, H. L., Vilar, C. C., Joyeux, J. C., ... Favaro, L. F. (2013). Analysis of fish assemblages in sectors along a salinity gradient based on species, families and functional groups. Brazilian Journal of Oceanography, 61, 251-264. https:// doi.org/10.1590/S1679-87592013000400006

Payan, P., Pontual, H., Boeuf, G., \& Mayer-Gostan, N. (2004). Endolymph chemistry and otolith growth in fish. General Palaeontology, 3, 535547. https://doi.org/10.1016/j.crpv.2004.07.013

Popper, A. N., \& Fay, R. R. (2011). Rethinking sound detection by fishes. Hearing Research, 273, 25-36. https://doi.org/10.1016/j.heares.2009.12.023

Siegle, E., Dottorl, M., \& Villamarin, B. C. (2017). Hydrodynamics of a subtropical tidal flat: Araçá Bay, Brazil. Ocean and Coastal Management, 164, 4-13.

Strong, M. B., Neison, J. D., \& Hunt, J. J. (1986). Aberrant crystallization of Pollock (Pollachius virens) otoliths. Canadian Journal of Fisheries Aquatic Science, 43, 1457-1462. https://doi.org/10.1139/f86-180
Sweeting, R. M., Beamish, R. J., \& Neville, C. M. (2004). Crystalline otoliths in teleosts: Comparisons between hatchery and wild coho salmon (Oncorhynchus kisutch) in the Strait of Georgia. Reviews in Fish Biology and Fisheries, 14, 361-369. https://doi.org/10.1007/ s11160-005-3793-3

Tomás, J., Geffen, A. J., Allen, I. S., \& Berges, J. (2004). Analysis of the soluble matrix of vaterite otoliths of juvenile herring (Clupea harengus): Do crystalline otoliths have less protein? Comparative Biochemistry and Physiology, 139, 301-308. https://doi.org/10.1016/j. cbpb.2004.09.013

Tzeng, W. N., Chang, C. W., Wang, C. H., Shiao, J. C., lizuka, Y., Yang, Y. J., ... Lozys, L. (2007). Misidentification of the migratory history of anguillid eels by $\mathrm{Sr} / \mathrm{Ca}$ ratios of vaterite otoliths. Marine Ecology Progress Series, 348, 285-295. https://doi.org/10.3354/meps07022

How to cite this article: de Carvalho BM, Volpedo AV, Albuquerque CQ, Fávaro LF. First record of anomalous otoliths of Menticirrhus americanus in the South Atlantic. J Appl Ichthyol. 2019;00:1-6. https://doi.org/10.1111/jai.13979 